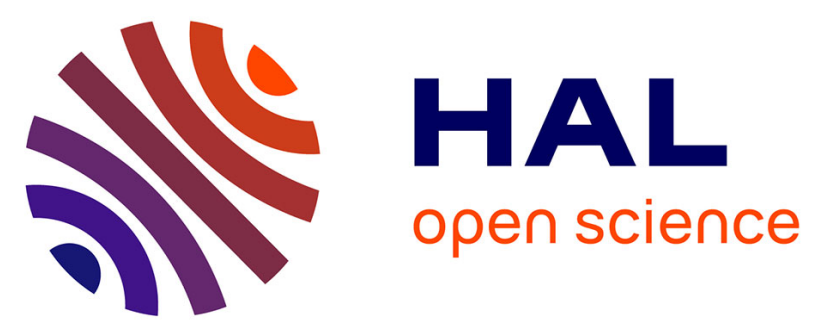

\title{
Spatial and Temporal Variability of Diffusive CO 2 and CH 4 Fluxes From the Amazonian Reservoir Petit-Saut (French Guiana) Reveals the Importance of Allochthonous Inputs for Long-Term C Emissions
} Fanny Colas, Vincent Chanudet, Martin Daufresne, Lucie Buchet, Régis

Vigouroux, Angélique Bonnet, Frederick Jacob, Jean-marc Baudoin

\section{To cite this version:}

Fanny Colas, Vincent Chanudet, Martin Daufresne, Lucie Buchet, Régis Vigouroux, et al.. Spatial and Temporal Variability of Diffusive CO 2 and CH 4 Fluxes From the Amazonian Reservoir PetitSaut (French Guiana) Reveals the Importance of Allochthonous Inputs for Long-Term C Emissions. Global Biogeochemical Cycles, 2020, 34 (12), 10.1029/2020GB006602 . hal-03161901

\author{
HAL Id: hal-03161901 \\ https: / hal.inrae.fr/hal-03161901
}

Submitted on 8 Mar 2021

HAL is a multi-disciplinary open access archive for the deposit and dissemination of scientific research documents, whether they are published or not. The documents may come from teaching and research institutions in France or abroad, or from public or private research centers.
L'archive ouverte pluridisciplinaire HAL, est destinée au dépôt et à la diffusion de documents scientifiques de niveau recherche, publiés ou non, émanant des établissements d'enseignement et de recherche français ou étrangers, des laboratoires publics ou privés. 


\section{Biogeochemical Cycles}

\author{
RESEARCH ARTICLE \\ 10.1029/2020GB006602 \\ Key Points: \\ - Petit-Saut reservoir exhibited high \\ temporal and spatial variability in \\ dissolved $\mathrm{CO}_{2}$ and $\mathrm{CH}_{4}$ \\ concentrations \\ - Variability in dissolved gas \\ concentrations was likely related to \\ heterogeneity of carbon sources that \\ also vary in time and space \\ - Transitional and littoral areas \\ exhibited higher $\mathrm{C}$ emissions than \\ open areas suggesting the \\ importance of allochthonous inputs \\ for the current gross emissions
}

Supporting Information:

- Supporting Information S1

Correspondence to:

F. Colas,

fanny.colas@univ-lyon1.fr

Citation:

Colas, F., Chanudet, V., Daufresne, M. Buchet, L., Vigouroux, R., Bonnet, A., et al. (2020). Spatial and temporal variability of diffusive $\mathrm{CO}_{2}$ and $\mathrm{CH}_{4}$ fluxes from the Amazonian reservoir Petit-Saut (French Guiana) reveals the importance of allochthonous inputs for long-term C emissions. Global

Biogeochemical Cycles, 34, e2020GB006602. https://doi.org/ 10.1029/2020GB006602

Received 12 MAR 2020 Accepted 29 NOV 2020 Accepted article online 8 DEC 2020

(C)2020. American Geophysical Union. All Rights Reserved.
Spatial and Temporal Variability of Diffusive $\mathrm{CO}_{2}$ and $\mathrm{CH}_{4}$ Fluxes From the Amazonian Reservoir Petit-Saut (French Guiana) Reveals the Importance of Allochthonous Inputs for Long-Term C Emissions

Fanny Colas ${ }^{1}$ (D), Vincent Chanudet ${ }^{2}$, Martin Daufresne ${ }^{3,4}$, Lucie Buchet ${ }^{3,4}$, Régis Vigouroux ${ }^{5}$, Angélique Bonnet ${ }^{3,4}$, Frederick Jacob ${ }^{2}$, and Jean-Marc Baudoin ${ }^{3,6}$

${ }^{1}$ Univ Lyon, Université Claude Bernard Lyon 1, CNRS, ENTPE, Villeurbanne, France, ${ }^{2}$ Electricité de France, Hydro Engineering Centre, Environnemental and Social Dpt, La Motte Servolex, France, ${ }^{3}$ Pôle R\&D (ECLA), Aix-en-Provence, France, ${ }^{4}$ Inrae, Aix Marseille Univ, RECOVER, Aix-en-Provence, France, ${ }^{5}$ Hydreco Guyane, Laboratoire Environnement de Petit-Saut, Kourou, France, ${ }^{6}$ OFB, Direction de la Recherche et de l'Appui Scientifique, Aix-en-Provence, France

Abstract Variability in greenhouse gas emissions from reservoirs creates uncertainty in global estimates of $\mathrm{C}$ emissions from reservoirs. This study examines the temporal and spatial variability in $\mathrm{CO}_{2}$ and $\mathrm{CH}_{4}$ surface water concentrations and diffusive fluxes from an Amazonian reservoir using an original data set combining both a high temporal ( 1 central site $\times 22$ years) and spatial ( 44 sites $\times 1$ season) resolution monitoring. The gas concentrations at the central site decreased over time and suggested reduced bioavailability of $\mathrm{C}$ in the initial flooded soil but exhibited strong seasonal variation. Not accounting for this variability may result in uncertainties in estimates of annual concentrations (ranging from $-68.9 \%$ to $+260 \%$ for $\mathrm{CH}_{4}$ and from $-71.5 \%$ to $+156 \%$ for $\mathrm{CO}_{2}$ ) and thus in estimates of diffusive gas emissions. Gas concentrations and diffusive fluxes exhibited high spatial variability in the reservoir, 24 years after impoundment. In particular, diffusive fluxes were higher in littoral and transitional areas than in open areas, suggesting a large contribution of allochthonous $\mathrm{C}$ to current gaseous emissions. Not accounting for this spatial variability in diffusive fluxes may underestimate the total emissions expressed in $\mathrm{CO}_{2}$ equivalents from the whole reservoir by $50.7 \%$. Our study stresses the importance of well-resolved temporal and spatial monitoring to provide reliable estimated of $\mathrm{C}$ emissions and a comprehensive understanding of the processes involved; both of these inputs are needed to support decision-making for developing energy strategies.

Plain Language Summary While touted as a low carbon source of electricity, some tropical hydropower reservoirs were reported to emit substantial quantities of dioxide carbon and methane. Tropical reservoirs, especially those located in the lowland reaches of Amazon basin, are the greatest reservoir emitters on the planet. Despite this, hundreds of dams are set to be constructed in these areas. In the context of global warming and the expanding growth of hydroelectricity, the quantification of greenhouse gas emissions from tropical reservoirs is recognized as a priority. Yet emissions vary greatly in time and space. Such variability has to be addressed to provide reliable estimates of carbon emissions from reservoirs and to guide energy decision-making. With long-term monitoring of a 24 year old Amazonian reservoir, we reported high gaseous concentrations in the first years following impoundment due to the mineralization of the large stock of carbon coming from the flooded rainforest. The past 10 years, concentrations have significantly decreased with the reduced bioavailability of flooded carbon. Yet the variability of gaseous concentrations within the reservoir reveals the importance of carbon inputs coming from numerous tributaries and the surrounding rainforest for explaining long-term emissions from the reservoir. Not accounting for such spatial variability may lead to significant underestimates of gross greenhouse emissions from Amazonian reservoirs.

\section{Introduction}

Although the emissions of greenhouse gas (GHG) by reservoirs has been intensively studied in the last decade, predicting the diffusive $\mathrm{CO}_{2}$ and $\mathrm{CH}_{4}$ emissions from reservoirs is still challenging because of the 
difficulty in representing the spatial and temporal variability of gas fluxes (e.g., Abril et al., 2005; Paranaíba et al., 2018; Roland et al., 2010). Yet such knowledge is necessary in light of the growing demand for energy and numerous dams that are planned for construction in the world as a result of this. Among reservoirs, tropical systems are hot spots for $\mathrm{C}$ emission (Barros et al., 2011). In particular, Amazonian reservoirs are the highest emitting dams on the planet (e.g., Barros et al., 2011; Kemenes et al., 2011; Ometto et al., 2013; Pacheco et al., 2015) notably those located at lowland reaches (Almeida et al., 2019). Yet the majority of the world's hydropower potential remains in the tropics and particularly in 187 large dams that are under construction or planned in the Amazon basin over the next 2 decades (De Faria et al., 2015; Zarfl et al., 2015). Despite this, there is a paucity of data on $\mathrm{C}$ emissions from tropical reservoirs, especially Amazonian ones, and the drivers involved remain unclear. As a result, they are still poorly represented in the most recent global estimates (e.g., Deemer et al., 2016; Raymond et al., 2013).

High gaseous emissions in tropical reservoirs were related to high water temperatures and the flooding of large stocks of above- and below-ground C especially for Amazonian reservoirs surrounded by dense rainforest (e.g., Delmas et al., 2005; DelSontro et al., 2018; Fearnside, 1995; Galy-Lacaux et al., 1999; Rosa et al., 2003). Some studies addressed temporal changes in gaseous emissions from tropical reservoirs using rare long-term monitoring data (Abril et al., 2005) or compared reservoirs with different ages of impoundment (e.g., Rosa et al., 2003; St. Louis et al., 2000). Such studies reported that the gaseous emissions are maximal in the first 2 to 3 years after impounding because of the microbial decomposition of the more labile faction of the flooded terrestrial organic matter (OM). Then, gaseous emissions slowly decrease with the decrease in quantity and bioavailability of the OM remaining at the bottom of the reservoirs (Campo \& Sancholuz, 1998; Guérin et al., 2008; Tremblay, 2005). At Petit-Saut reservoir (French Guiana), long-term monitoring has revealed that 10 years after impounding, the OM mineralization of flooded soils and vegetation was still the major contributor (i.e., 75-95\%) to its gas emissions (Abril et al., 2005; Guérin et al., 2008). Yet temporal data such as this on gaseous emission are rare and therefore the long-term fate of flooded OM remains unclear as well as the contribution of other C sources to GHG.

Most studies in the past on reservoir GHG production or emission look at these emissions at a single site, usually in the open area close to the dam, which is supposed to be representative of the water body. This is probably true for young reservoirs since the labile component of the flooded terrestrial OM is the major contributor of gas emission in the first years following impoundment, even if different regions of the reservoirs may have different flooded biomass resulting in spatial heterogeneity in GHG emissions (Paranaíba et al., 2018). Nevertheless, the contribution of the initial pool of flooded OM to gaseous emissions from reservoirs is expected to decrease with time, and conversely, the contribution of allochthonous OM is expected to increase (Guérin et al., 2008). The contribution of other C sources including autochthonous (e.g., phytoplankton and periphytic algae) and allochthonous (e.g., lateral or river inputs of $\mathrm{C}$ from terrestrial ecosystems) to gaseous emissions has been scarcely quantified and integrated into $\mathrm{C}$ budgets used to predict emissions from reservoirs over long time scales. Yet the contribution of such $\mathrm{C}$ sources may be important, especially for Amazonian reservoirs, for which allochthonous inputs are expected to be significant given their complex shape (i.e., dendritic, with many small tributaries and forested islands) and the surrounding dense rainforest.

This heterogeneity in $\mathrm{C}$ sources and inputs may lead to high spatial variability in $\mathrm{C}$ dynamics and gaseous emissions. Reservoirs exhibit distinct and interacting limnological longitudinal (i.e., riverine, transitional, and lacustrine; Thornton, 1990) and lateral (i.e., littoral and open-water pelagic; Wetzel, 2001) zones that affect their chemistry and their biology. In particular, this results in great spatial heterogeneity with respect to $\mathrm{C}$ inputs (e.g., allochthonous or autochthonous) and dynamics, which therefore affects the production and emission of GHGs. For instance, littoral zones typically exhibit high plant biomass that replaces itself several times per year, especially in the drawdown area, which causes inputs of nonliving dissolved and particulate OM into the water column and sediments, resulting to higher gaseous emission than in pelagic areas (e.g., Almeida et al., 2016; Chen et al., 2009; Deshmukh et al., 2014; Yang et al., 2012). In the transitional zone, flow velocity slows as the basin becomes wider and deeper, resulting in high loads and rapid burial of organic and inorganic material that may foster high rates of $\mathrm{CH}_{4}$ production and ebullition (Chanudet et al., 2020; DelSontro et al., 2011; Maeck et al., 2013; Sobek et al., 2012) and $\mathrm{CO}_{2}$ emissions (e.g., Cardoso et al., 2013). In particular, the spatial variability of $\mathrm{CO}_{2}$ and $\mathrm{CH}_{4}$ surface 
water concentrations and emissions is expected to be large for tropical reservoirs due to their dendritic shape that is formed by the input of numerous secondary tributaries. Additionally, each reservoir arm may exhibit differential water retention time (Nogueira et al., 2019) and wind regimes that may influences gas emissions (Pacheco et al., 2015). This spatial variability may cause inaccuracies in estimates of gas emissions from reservoirs when not taken into account by studies (Paranaíba et al., 2018; Roland et al., 2010) along with ignorance of drivers involved in C dynamics and long-term emissions (Raymond et al., 2013).

The Petit-Saut reservoir in French Guiana constitutes an ideal case study for examining temporal and spatial variation in GHG concentrations and diffusive fluxes because the dam manager has performed intensive monitoring since its flooding in 1994. In particular, $\mathrm{CO}_{2}$ and $\mathrm{CH}_{4}$ concentrations measured monthly at one central site since impoundment were used to address temporal changes in the contribution of initial terrestrial flooded $\mathrm{C}$ to gaseous emissions. Based on observations from this central site, we hypothesized that the $\mathrm{CO}_{2}$ and $\mathrm{CH}_{4}$ concentrations would decrease over time due to the degradation of preflooded soil OM. However, we expected strong seasonal variation in gas concentrations that may lead to uncertainties in estimates of gas emissions from the reservoir when based on annual monitoring. We then investigated the spatial variability in gaseous surface water concentrations, diffusive fluxes, and the environmental drivers potentially involved in these processes by using recent field measurements performed during the dry season, 24 years after impoundment, at 44 sites in the reservoir. We hypothesized that allochthonous $\mathrm{OM}$ would contribute significantly to current diffusive $\mathrm{CO}_{2}$ and $\mathrm{CH}_{4}$ emissions from the reservoir and result in higher emissions in sites located in transitional and littoral areas than in open areas, including the monthly monitoring site "Roche Genipa." This would contribute to the underestimation of total current diffusive emissions from the reservoir when upscaling with the emissions measured at the only monitored site.

\section{Materials and Methods}

\subsection{The Petit-Saut Reservoir}

Petit-Saut (PSR) is a lowland reservoir (<200 m a.s.l.) located in the Amazon rainforest of French Guiana on the Sinnamary river $\left(5^{\circ} 03^{\prime} \mathrm{N}, 53^{\circ} 02^{\prime} \mathrm{W}\right)$. The climate is tropical, hot, and humid throughout the year, with a dry season (in February/March and from July to November) and a rainy season (December/January and April to June). The reservoir covers $80 \mathrm{~km}$ of the river course. Impounding started in January 1994 and was completed in July 1995. The maximal depth of the PSR is $35 \mathrm{~m}$, and the water level varies between 31.5 and $35 \mathrm{~m}$ depending on exploitation of the hydroelectric station and on rainfall events. At its maximum operating level, the reservoir volume is close to $3.5 \mathrm{~km}^{3}$, and the annual mean discharge of the Sinnamary river is $267 \mathrm{~m}^{3} \mathrm{~s}^{-1}$. The average residence time is estimated to be about 5 months. The reservoir water body in deep zones remains stratified throughout the year with an oxic epilimnion and an anoxic hypolimnion, separated by a quasi-permanent oxycline located at depths of 5-7 m (Figure 2e). During impounding, approximately $365 \mathrm{~km}^{2}$ of uncleared tropical forest were flooded. Twenty-four years after impoundment, dead tree trunks are still emerging from the water, and the flooded forest covers the whole of the reservoir except in the original channel of rivers and a small clearcut zone near the dam. The total amount of flooded biomass (named "Flooded C" hereafter), including above-ground vegetation (170 t C ha ${ }^{-1}$ ) and soil carbon (100 t C ha ${ }^{-1}$ ) amounted to around 10 million tons of carbon (Galy-Lacaux et al., 1999). The impoundment led to the creation of $105 \mathrm{~km}^{2}$ of small islands (Huynh et al., 1996). In addition, PSR intercepts 255 streams (BD CARTHAGE ${ }^{\circledR}$ Guyane) including the main tributary (Sinnamary river), producing numerous transitional areas and a dendritic shape. This dendritic shape provides a long shoreline (about 3,773 $\mathrm{Km}$ ) and, combined with the low slope, a large area of shallow littoral habitats.

\subsection{Temporal Data Collection on Gas Concentrations}

Concentrations in $\mathrm{CH}_{4}$ and $\mathrm{CO}_{2}$ and limnological parameters (e.g., oxygen concentrations and temperature) were monitored on a monthly basis at station "Roche Genipa" (water depth: 30 to 35 m; Figure S1 in the supporting information) from 2 years after the impoundment in 1994, except for $\mathrm{CO}_{2}$ concentrations in deep water (since 2003). This site was historically chosen as the most representative station in the reservoir for average gas concentrations. (Abril et al., 2005). This site is located at the central part of the reservoir near the axis of the Sinnamary channel. At this site, water for gas concentrations was sampled in $40 \mathrm{ml}$ serum 
bottles every 3 to $5 \mathrm{~m}$ from the surface to the bottom. Then, $\mathrm{CH}_{4}$ and $\mathrm{CO}_{2}$ concentrations were measured with a gas chromatograph (8610 C, SRI) equipped with a flame ionization detector (FID) and a FID methanizor, respectively, after creating a $20 \mathrm{ml} \mathrm{N}$ headspace as described in Guérin and Abril (2007). The dissolved oxygen (DO) concentrations and temperature profiles were measured using a YSI multiparameter probe (Model 6600) according national standards (NF EN 25814). The package rLakeAnalyzer (Winslow, 2019) was used for calculating the thermocline depth. Then, the average concentrations of gas were calculated for the epilimnion (hereafter "surface water concentrations") and the hypolimnion (hereafter "concentrations in deeper water layers"). The DO concentration of the main tributary at the entrance to the reservoir averages $4.6 \mathrm{mg} \mathrm{L}^{-1}$. Therefore, we determined the depth at which the DO concentrations were inferior to $4 \mathrm{mg} \mathrm{L}^{-1}$ and reach anoxia.

\subsection{Spatial Variability of Gas Surface Water Concentrations 2.3.1. Study Sites and Data Collection}

A field campaign was run during the dry season in 2018 on 44 sampling sites (Figure S1) selected for covering a range of environmental conditions representing the heterogeneity of $\mathrm{C}$ sources (e.g., $\mathrm{C}$ of flooded forest and $\mathrm{C}$ inputs from rivers or the riparian forest). Selected sites covered open water (i.e., near the original channel, deep water, and no flooded forest), transitional zone (i.e., near the river input, shallow water, and no flooded forest), and littoral area (i.e., near the bank, shallow water, and flooded forest). For each site, coordinates were uploaded in GPS (Garmin, GPSMAP ${ }^{\circledR} 62$ ), and depth was reported using a depth sounder (Echotest II, Plastimo, France). Wind speed $\left(\mathrm{m} \mathrm{s}^{-1}\right)$ at $2 \mathrm{~m}$ above the water surface and atmospheric pressure has been measured three times using a portable anemometer (Xplorer 4 Skywatch, accuracy: wind $\pm 3 \%$ FS; pressure $\pm 1 \mathrm{hPa}$ ). Wind speed measurements were then normalized to wind speed at $10 \mathrm{~m}\left(U_{10}\right)$ above water level using the formula of Amorocho and DeVries (1980). Field equipment (YSI EXO2 portable multiparameter probe) was used to determine the depth profiles of chlorophyll a, DO, temperature, $\mathrm{pH}$, dissolved OM, turbidity, and conductivity. A Secchi disk was used to measure water transparency. Sediments were sampled using an Ekman grab (sampling depth of $20 \mathrm{~cm}$ ) to carry out a visual examination of the sediment (e.g., percent in leaf/detritus and in fine and coarse sediment). $\mathrm{CH}_{4}$ and $\mathrm{CO}_{2}$ partial pressure were measured at $0.5 \mathrm{~m}$ depth using submersible gas sensors ( $M i n i \mathrm{CH}_{4}{ }^{\mathrm{TM}}$, Mini $\mathrm{CO}_{2}{ }^{\mathrm{TM}}$, ProOceanus, Nova Scotia, Canada) operating through the diffusion of dissolved gases from liquids through a supported semipermeable membrane to a nondispersive infrared detector (NDIR). Three measurements points were performed for each sampling sites. For each point, gas surface water concentrations were measured every minute for $12 \mathrm{~min}$ total and corrected by the response time of the online equilibration system, which was 3 min for $\mathrm{CO}_{2}$ and 8 min for $\mathrm{CH}_{4}$. The solubility coefficients of Weiss (1974) and Yamamoto et al (1976) were used to compute the $\mathrm{CO}_{2}$ and $\mathrm{CH}_{4}$ surface water concentrations, respectively. Repeatability on triplicates was better than 5\%. The collected data are described in detail in the supporting information (Table S1). In addition, rainfall $\left(\mathrm{mm} \mathrm{hr}^{-1}\right)$ was measured with a meteorological station near the dam.

\subsubsection{Estimation of Diffusive Gas Fluxes From Concentrations}

The diffusive air-water flux of gas $\left(\mathrm{mmol} \mathrm{m}^{-2}\right.$ day $\left.^{-1}\right)$ depends on the concentration gradient over the air-water interface and the gas transfer velocity $(k)$ for a given gas at a given temperature according the equation proposed by Cole and Caraco (1998):

$$
F_{g, T}=k\left(C_{w}-C_{e q}\right)
$$

where $k_{g, T}$ is the gas transfer velocity for the given gas $\left(\mathrm{cm} \mathrm{hr}^{-1}\right), C_{w}$ is the concentration of the given gas in water at $0.5 \mathrm{~m}$ depth $\left(\mu \mathrm{mol} \mathrm{L}{ }^{-1}\right)$, and $C_{e q}$ is the theoretical concentration in the water of the given gas if the water phase were in equilibrium with the atmosphere $\left(\mu \mathrm{mol} \mathrm{L}{ }^{-1}\right)$. The equilibrium with the atmosphere was assumed to correspond to 399.5 and $1.83 \mu$ atm for $\mathrm{CO}_{2}$ and $\mathrm{CH}_{4}$, respectively (Blasing, 2009). The gas transfer velocity $k$ for $\mathrm{CO}_{2}$ and $\mathrm{CH}_{4}$ was calculated following the equation (Jähne et al., 1987)

$$
k_{g, T}=k_{600}\left(S c_{g, T} / 600\right)^{-n}
$$

where $n=0.66$ for wind speed $<3.7 \mathrm{~m} \mathrm{~s}^{-1}$ (Jähne et al., 1987; Liss \& Merlivat, 1986), Sc is the Schmidt number of a given gas at a given temperature (Wanninkhof, 1992), and $k_{600}$ was calculated from the wind speed and the rainfall during the field experiment using the equation of Guérin et al. (2007) specifically computed for Petit-Saut reservoir: 


$$
k_{600}=1.66 \cdot e^{0.26 \cdot U_{10}}+0.66 R,
$$

where $U_{10}$ is the wind speed $\left(\mathrm{m} \mathrm{s}^{-1}\right)$ at $10 \mathrm{~m}$ and $R$ in the rainfall $\left(\mathrm{mm} \mathrm{hr}^{-1}\right) . k_{600}$ was computed using average rainfall rates $\left(0.05 \mathrm{~mm} \mathrm{hr}^{-1}\right)$ during the field experiment and average wind speed for open water $\left(1.6 \mathrm{~m} \mathrm{~s}^{-1}\right)$, transitional $\left(1.2 \mathrm{~m} \mathrm{~s}^{-1}\right)$, or littoral $\left(1.0 \mathrm{~m} \mathrm{~s}^{-1}\right)$ sites. The $k_{600}$ ranged from 2.3 to $2.5 \mathrm{~cm} \mathrm{hr}^{-1}$.

The diffusive fluxes were also expressed in $\mathrm{CO}_{2}$ equivalents $\left(\mathrm{CO}_{2}\right.$-eq) by summing the contribution of both $\mathrm{CO}_{2}$ and $\mathrm{CH}_{4}$. For this purpose, diffusive fluxes were previously converted into $\mathrm{g} \mathrm{m}^{-2}$ day ${ }^{-1}$, and a global warming potential for $\mathrm{CH}_{4}$ of 28 was taken assuming a period of 100 years and no carbon feedback loop (IPCC, 2014). Finally, the annual diffusive fluxes of $\mathrm{C}$ were calculated using the reservoir surface area during the experiment (i.e., $333 \mathrm{~km}^{2}$ ).

\subsection{Spatial Modeling and Statistical Analyses}

R software (R Development Core Team, 2008) was used for all statistical analyses. Time series analyses and coefficients of variation (CVs) were used to describe the temporal dynamics of $\mathrm{CH}_{4}$ and $\mathrm{CO}_{2}$ concentrations (in surface and depth) and DO threshold of $4 \mathrm{mg} \mathrm{L}^{-1}$ at the monthly monitored site "Roche Genipa." Time series were log transformed to make seasonal and random fluctuations more constant over time. A seasonal and trend decomposition based on loess smoothing (STL) was used for decomposing the log transformed time series into trend, seasonal, and remainder components (Cleveland et al., 1990). The trend component indicates a general direction of the overall data. The seasonal component is a regular and predictable pattern that occurs at a fixed interval of time (monthly, here). The seasonal effect of each month was estimated by averaging values of the detrended series for each month over all years and then was normalized (seasonal factor). The CV was calculated for all data on annual mean concentrations of gas and for each year on monthly concentrations to gauge the magnitude of between- and within-year temporal variability, respectively. We used the percent error to gauge the uncertainty related to gas emission estimates when based on monitoring of gas concentration at low frequency (e.g., one sampling time per year). The percent error was calculated for each year as a maximal range of uncertainty related to a single sampling time when surface gas concentrations were minimal (underestimation) or maximal (overestimation). For each of the sites sampled during the 2018 dry season, the distances to the nearest tributary, rivers channels, and banks (including islands and reservoir banks) were calculated using the software ArcGIS (10.3). Transitional areas were assumed for sites with a distance to tributary shorter than $1,000 \mathrm{~m}$. Shallow sites ( $<6 \mathrm{~m}$ depth) located at less of $100 \mathrm{~m}$ from the banks and at more of $300 \mathrm{~m}$ from the channel were considered as belonging to the littoral area. Variograms were used to evaluate the spatial correlation of gas concentrations among sampling sites and to interpolate them spatially using ordinary kriging. Reliability of interpolation has been checked using fivefold cross-validation. The mean standardizing error was low $(<0.05)$. Principal component analyses (PCAs) were carried out to investigate the sampling site distribution according to spatial variables (i.e., $X$ and $Y$ coordinates, distances to channel, tributary, and banks) and depth. The coordinates of each sites on PCA's axes were used as synthetic variables of spatial position of sites within the reservoir. Then, relationships between gas concentrations and the synthetic variables were examined using Spearman's rank correlation coefficient. Relationships between gas concentrations and the environmental variables (as a set of explanatory variables) were modeled using redundancy analyses (RDA) (Legendre \& Legendre, 2012). Prior to run RDA, explanatory variables have been centered, standardized, and transformed and collinearity between the responses variables have been checked using Spearman's correlation tests. For each set of explanatory variables, a RDA has been run for which explanatory variables have been selected by stepwise selection that removes nonsignificant explanatory variables (Blanchet et al., 2008; Legendre \& Legendre, 2012). The significance of each model and of each canonical axis has been tested using the function "anova." The CVs were calculated to gauge the magnitude of spatial variability in gas concentrations and emissions among reservoir sites. Percent error was used to gauge the magnitude of the uncertainty related to gas emission estimates based on observations from a single sampling location ("Roche Genipa," the long-term sampling location) compared to observations from the 44 sites belonging to the field campaign performed during the dry season in 2018. Specific packages used for statistical analyses were ade4 (Chessel et al., 2004), "automap" (Hiemstra \& Hiemstra, 2013), "gstat” (Pebesma et al., 2018), "vegan” (Oksanen et al., 2013), and "forecast” (Hyndman et al., 2019). 


\section{Results}

\subsection{Temporal Dynamics of $\mathrm{CH}_{4}, \mathrm{CO}_{2}$, and DO Concentrations}

$\mathrm{CH}_{4}$ and $\mathrm{CO}_{2}$ concentrations at station Roche Genipa exhibited high between- and within-year variability since impounding (Figure 1). The CVs calculated on annual average concentrations were 92.8\% (surface water) and $116.8 \%$ (deeper water layers) for $\mathrm{CH}_{4}$ concentrations and $66.3 \%$ (surface water) and 51.4\% (deeper water layers) for $\mathrm{CO}_{2}$ concentrations. Surface water concentration in $\mathrm{CH}_{4}$ exhibited more temporal fluctuations than deep concentrations (Figure 1). The estimated trend elucidates high $\mathrm{CH}_{4}$ surface water concentrations since impoundment in 1994 until $2009\left(1.19 \pm 1.0 \mu \mathrm{mol} \mathrm{L}{ }^{-1}\right)$ followed by a strong decrease and steady low concentrations $\left(0.48 \pm 0.16 \mu \mathrm{mol} \mathrm{L}^{-1}\right)$ from then, while some extreme events occurred (Figure S2). The estimated trend component of $\mathrm{CH}_{4}$ concentrations in deeper water layers shows a gradual decrease since impoundment in 1994 to an average concentration of $40.0 \mu \mathrm{mol} \mathrm{L}{ }^{-1}$ in 2016 , punctuated by a few high-concentration events (Figure S2). Additionally, $\mathrm{CH}_{4}$ and $\mathrm{CO}_{2}$ concentrations exhibited high monthly seasonality in surface (average CV: $96.1 \pm 53.7 \%$ for $\mathrm{CH}_{4}$ and $68.1 \pm 22.0 \%$ for $\mathrm{CO}_{2}$ ) and in depth (CV: $109.4 \pm 35.3 \%$ for $\mathrm{CH}_{4}$ and $42.2 \pm 10.5 \%$ for $\mathrm{CO}_{2}$ ). In particular, the largest seasonal factor for the $\mathrm{CH}_{4}$ surface water concentrations is for August (0.66) and the lowest for June (-0.31). For CH4 concentrations in deeper water layers, the largest seasonal factor is for December (2.03) and the lowest for July (-2.06). This indicates a peak in $\mathrm{CH}_{4}$ concentration at the beginning and at the end of the dry season and a decrease at the end of the wet season in surface and in depth, respectively. For $\mathrm{CO}_{2}$ concentrations, the largest seasonal factor is for August (0.24) and for December (0.54) in surface and in depth, respectively. The lowest is for March (-0.26) and for July (-0.32), respectively. This indicates a peak in $\mathrm{CO}_{2}$ surface water concentrations in August and a decrease in March. For $\mathrm{CO}_{2}$ concentrations in deeper water layers, this indicates a peak at the end of dry season and conversely, the lowest value at the beginning. The percent error related to within-year variability of surface water gas concentrations ranged from $-68.9 \pm 15.8 \%$ to $+260.6 \pm 193.2 \%$ for $\mathrm{CH}_{4}$ concentrations and from $-71.5 \pm 20.3 \%$ to $+156.6 \pm 63.4 \%$ for $\mathrm{CO}_{2}$ concentrations. DO levels also exhibited strong between- and within-year variations (Figure 1). In particular, the lowest seasonal factor for the depth of $4 \mathrm{mg}$ DO L $\mathrm{L}^{-1}$ threshold is for July $(-0.22)$. Then it increases to reach its maximum value in February (0.21). This indicates that the depth of water layers exhibiting DO concentrations inferior to $4 \mathrm{mg} \mathrm{L}^{-1}$ increased during the dry season and conversely decreased during the wet season. While such seasonal variations are strong, the DO concentrations tend to increase over time as exemplified by the depth of $4 \mathrm{mg} \mathrm{L}^{-1}$ threshold that increased from $-2.9 \mathrm{~m}$ in 1996 to $-5.4 \mathrm{~m}$ in 2016.

\subsection{Spatial Variability in Surface Water Gas Concentrations Within PSR \\ 3.2.1. Data Description}

Concentrations coming from direct measurements ranged from 8.5 to $199.2 \mu \mathrm{mol} \mathrm{L} \mathrm{L}^{-1}$ (mean \pm SD: $50.8 \pm 40.0 \mu \mathrm{mol} \mathrm{L}{ }^{-1}$ ) for $\mathrm{CO}_{2}$ and from 1.8 to $8.1 \mu \mathrm{mol} \mathrm{L} \mathrm{L}^{-1}$ (mean $\pm \mathrm{SD}: 4.0 \pm 1.0 \mu \mathrm{mol} \mathrm{L}{ }^{-1}$ ) for $\mathrm{CH}_{4}$ (Figure 2; Table S1). The concentrations calculated from gridded data varied from 6.4 to $243.7 \mu \mathrm{mol} \mathrm{L}^{-1}$

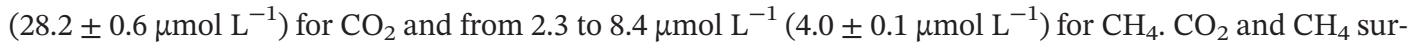
face water concentrations exhibited high spatial variability within the reservoir (CV: $78.9 \%$ and $25.4 \%$ for $\mathrm{CO}_{2}$ and $\mathrm{CH}_{4}$, respectively). $\mathrm{CO}_{2}$ and $\mathrm{CH}_{4}$ surface water concentrations tend to exhibit inverse spatial pattern within PSR. $\mathrm{CO}_{2}$ concentrations were higher in sites close to the river entrance and then decreased toward the dam. In contrast, the lowest $\mathrm{CH}_{4}$ surface water concentrations were measured near the main river entrance. The maximum concentration of $\mathrm{CO}_{2}$ was observed at the confluence with the main tributary, and the minimum was observed in the open water of the reservoir. For $\mathrm{CH}_{4}$ concentration, the maximum was observed in the flooded forest littoral area, and the minimum was observed in the flooded forest near the main channel in the middle of the reservoir.

\subsubsection{Spatial Variability of Gas Surface Water Concentrations}

The first two dimensions of the PCA (Figure 3) performed on spatial variables computed for the 44 sites resume $71.3 \%$ of the total inertia ( $\mathrm{PC} 1$ explains $49.7 \%$ of total variance and $\mathrm{PC} 221.6 \%$ ). The variables depth $(+0.87)$, distance at the confluence with the tributary $(+0.87)$, and $Y$ coordinates $(+0.80)$ are the most correlated to the first component. The variables distance to channel $(+0.65), X$ coordinates $(+0.64)$, and distance to the bank $(-0.69)$ are the most correlated to the second component. Variation captures by the first component separates sites located in the transition area (negative part) from sites located in the open and deepest area (positive part) along a longitudinal gradient. The second component separates sites near the banks to 


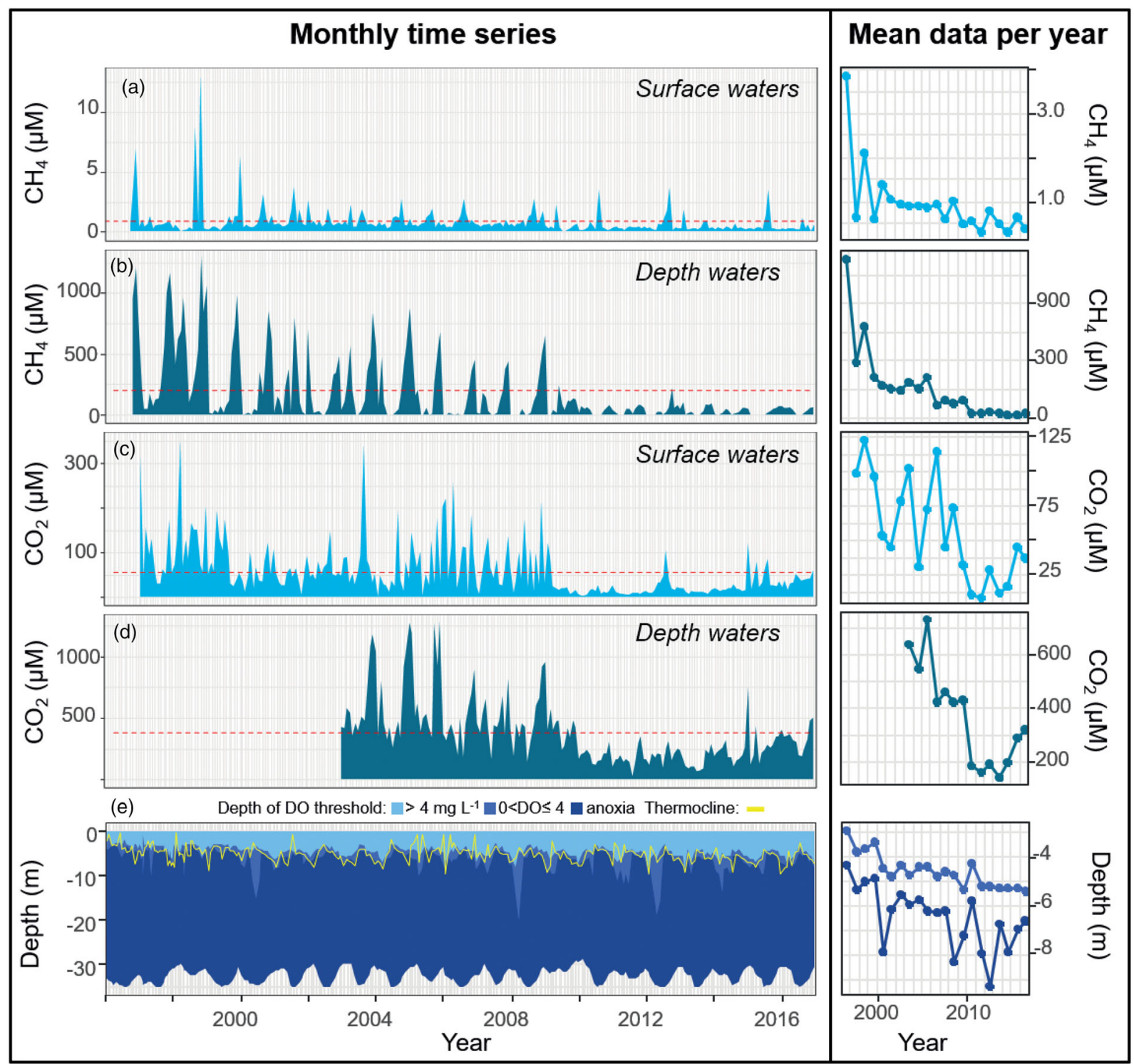

Figure 1. Temporal changes of gas concentrations in surface (a, c) and in depth (b, d) for $\mathrm{CH}_{4}$ and $\mathrm{CO}_{2}$, respectively, and depths of the thermocline and of DO thresholds (e) at station "Roche Genipa" since impounding. Red dotted lines show average values of concentrations for the time series for $\mathrm{CH}_{4}$ (i.e., $0.92 \pm 0.8,208.5 \pm 244.7 \mu \mathrm{mol} \mathrm{L}{ }^{-1}$ in surface and in depth, respectively) and for $\mathrm{CO}_{2}\left(56.5 \pm 37.5,379.9 \pm 261 \mu \mathrm{mol} \mathrm{L} \mathrm{L}^{-1}\right.$ in surface and in depth, respectively). Right panel shows the same data that the left panel but expressed as mean gas concentrations per year (from a to d) and as mean annual depths at which DO concentrations reach the threshold of $4 \mathrm{mg} \mathrm{L}^{-1}$ and anoxia (E).

sites near the river channels (i.e., transversal gradient). The $\mathrm{CO}_{2}$ surface water concentrations were negatively correlated with the first component $(\rho=-0.48, P<0.001)$, suggesting that highest concentrations were found in the transition areas. The $\mathrm{CH}_{4}$ surface water concentrations were negatively correlated with the second component $(\rho=0.47, P<0.05)$, meaning that sites located within the flooded forest near banks exhibited higher concentrations than sites located near the river channels. The ratios between $\mathrm{CH}_{4}$ and $\mathrm{CO}_{2}$ concentrations were highest in the open deep area near the dam $(\rho=0.51$, $P<0.001$ with PC1) and near the banks far from the channels $(\rho=-0.31, P<0.05$ with PC2).

\subsubsection{Environmental Factors Explaining the Variation in Gas Concentrations}

The RDA performed with spatial explanatory variables was significant and represented the first canonical axis (Figure 4a). The first two canonical axes explained $45.4 \%$ of the total variance, and the adjusted $R^{2}$ of this model was $36.6 \%$. Two explanatory variables were significant: the maximal water depth and $\mathrm{X}$ coordinate. 


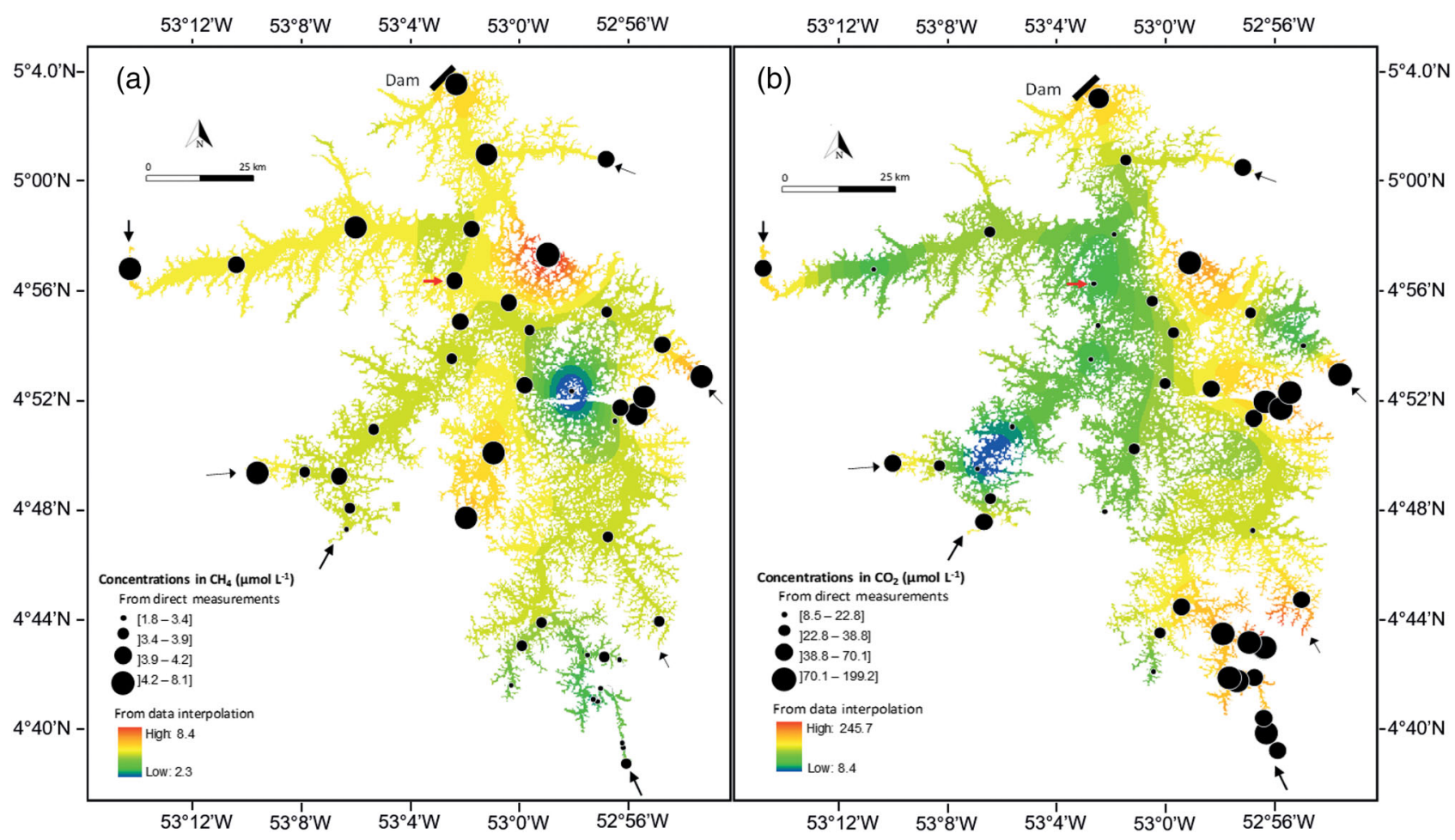

Figure 2. $\mathrm{CH}_{4}$ (a) and $\mathrm{CO}_{2}$ (b) concentrations $\left(\mu \mathrm{mol} \mathrm{L}{ }^{-1}\right.$ ) from direct measurements (black dots) and from ordinary kriging interpolation (color panel). The size of dots has been created using bubble function in R. The black arrows indicate the main river entrances. The red arrow indicates the monthly monitored site (named "Roche Genipa").

The proportion of the variance explained by these two variables is 39\%. The RDA performed with environmental data was also significant and explained $57.5 \%$ of the total variance (Figure $4 \mathrm{~b}$ ). The adjusted $R^{2}$ of this model was $50.9 \%$. Four explanatory variables were significant: the water temperature and the concentrations in DOM, in chla, and in DO. The proportion of the variance explained by these variables is $41.4 \%$. The partial RDA performed with variables selected by parsimonious RDA was significant as well as the first canonical axis. Environmental data explained $30.8 \%$ of the variance of gas concentrations, spatial covariables explained $18.4 \%$, and the interactions of these two types of variables explained $20.2 \%$. All these fractions were significant. The unexplained variation was $30.6 \%$.

\subsubsection{Consequences for Gas Emissions Estimation}

The diffusive flux ranged from -13.9 to $393.4 \mathrm{mmol} \mathrm{m}^{-2}$ day ${ }^{-1}$ (mean \pm SD: $86.5 \pm 79.5 \mathrm{mmol} \mathrm{m}^{-2}$ day $^{-1}$; $\mathrm{CV}=91.9 \%$ ) and from 2.6 to $12.4 \mathrm{mmol} \mathrm{m}^{-2}$ day $^{-1}$ (mean $\pm \mathrm{SD}: 5.5 \pm 1.9 \mathrm{mmol} \mathrm{m}^{-2} \mathrm{day}^{-1}$; $\mathrm{CV}=34.0 \%$ ) for $\mathrm{CO}_{2}$ and $\mathrm{CH}_{4}$, respectively. Fluxes in $\mathrm{CO}_{2}$ equivalents $\left(\mathrm{CO}_{2}\right.$-eq) varied from 55.9 to $430.8 \mathrm{mmol} \mathrm{m}^{-2}$ day $^{-1}$ (mean \pm SD: $142.5 \pm 77.6 \mathrm{mmol} \mathrm{m}^{-2} \mathrm{day}^{-1}, \mathrm{CV}=54.5 \%$; Figure 5) with higher emissions from transitional $\left(n=17\right.$; mean $\pm \mathrm{SD}: 164.2 \pm 87.2 \mathrm{mmol} \mathrm{m}^{-2}$ day $\left.{ }^{-1}\right)$ and littoral sites $(n=14 ;$ mean $\pm \mathrm{SD}$ : $\left.158.8 \pm 79.83 \mathrm{mmol} \mathrm{m}^{-2} \mathrm{day}^{-1}\right)$ than from open area sites $\left(n=13\right.$; mean $\left.\pm \mathrm{SD}: 96.3 \pm 35.0 \mathrm{mmol} \mathrm{m}^{-2} \mathrm{day}^{-1}\right)$. The proportion of emissions in $\mathrm{CO}_{2}$-eq supported by $\mathrm{CH}_{4}$ was higher in open area sites (mean $\pm \mathrm{SD}$ : $72.5 \pm 29.3 \%$ ) than in littoral (mean \pm SD: $49.0 \pm 27.6 \%)$ and transitional sites (mean \pm SD: $34.5 \pm 20.4)$ Conversely, the proportion supported by $\mathrm{CO}_{2}$ emissions was lower in open sites (mean \pm SD: $27.5 \pm 29.3 \%$ ) than in littoral and transition sites (mean \pm SD: $51.0 \pm 27.6$ and $65.5 \pm 20.4 \%$, respectively) The emissions in $\mathrm{CO}_{2}$ eq from the overall reservoir by upscaling of the mean diffusive flux measurements on the 44 sites were $0.77 \pm 0.41 \mathrm{Mt} \mathrm{CO}_{2}$ eq year ${ }^{-1}$ against $0.38 \pm 0.01 \mathrm{Mt} \mathrm{CO}_{2}$ eq year ${ }^{-1}$ considering only the monthly monitored site (i.e., Roche Genipa). The estimate of total emissions in $\mathrm{CO}_{2}$ eq based on observations from the long-term sampling site underestimated the total emissions by $50.7 \%$ compared to estimates based on the 44 sites due to a strong underestimation of diffusive $\mathrm{CO}_{2}$ emissions (-99.1\%). In contrast, observations from the long-term sampling site overestimated the diffusive $\mathrm{CH}_{4}$ emissions by $24.5 \%$. 


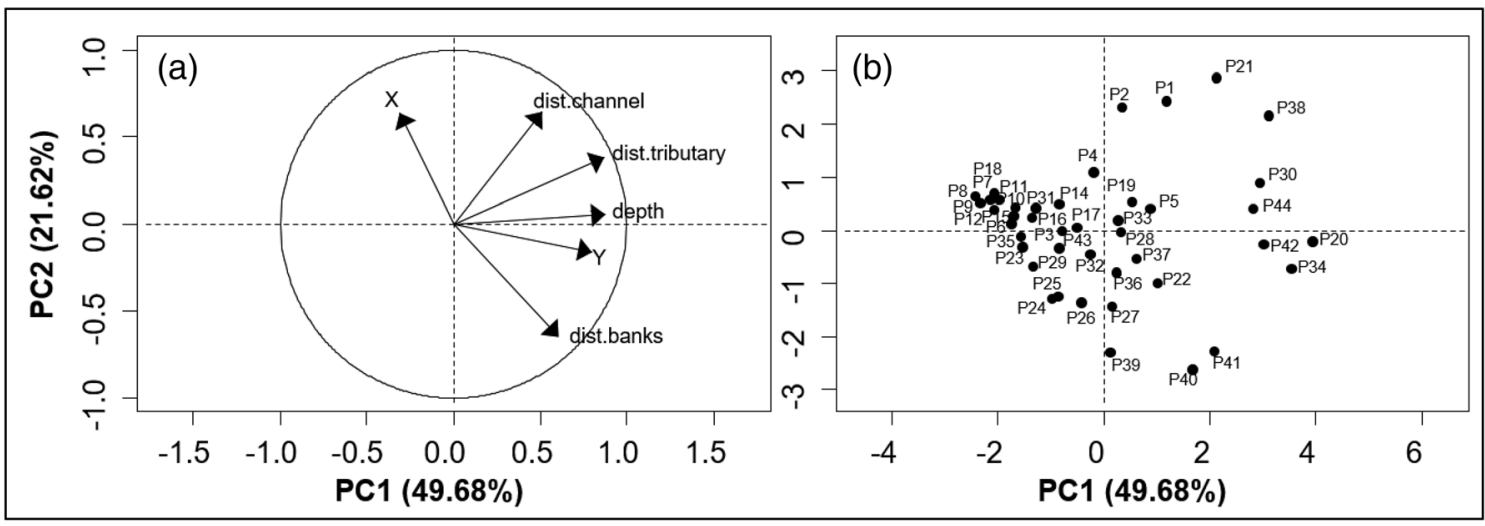

Figure 3. PCA performed on the spatial variables computed for the 44 sites: (a) correlation circle for the six spatial variables and (b) factorial plane for the 44 sites.

\section{Discussion}

The sources of $\mathrm{C}$ that drive the long-term emissions of reservoirs are still under debate notably due to the lack of temporally and spatially resolved data on gas emissions. Such high-resolution data are required notably for reservoirs, as the sources of $\mathrm{C}$ involved in gaseous emissions are known to vary considerably over space and time (e.g., Cardoso et al., 2013; De Junet et al., 2005, 2009; Pacheco et al., 2015). Addressing this variability is needed to provide better $\mathrm{C}$ flux estimates from reservoirs and their contribution to global $\mathrm{C}$ cycle and ultimately to guide public policies in implementation of low-carbon energy strategies. Intensive temporal and spatial monitoring of $\mathrm{CH}_{4}$ and $\mathrm{CO}_{2}$ concentrations and diffusive fluxes in PSR provided an opportunity to examine the spatiotemporal variability of gas concentrations and the consequences for $\mathrm{C}$ flux estimates.

\subsection{Temporal Variability of $\mathrm{CH}_{4}$ and $\mathrm{CO}_{2}$ Concentrations at Roche Genipa}

In particular, temporal data on the monthly monitored site at the central open site of PSR ("Roche Genipa") show that $\mathrm{CH}_{4}$ and $\mathrm{CO}_{2}$ concentrations exhibited high between- and within-year variability since impoundment in 1994. The between-year dynamic of $\mathrm{CH}_{4}$ concentrations in depth clearly demonstrates high concentrations the 4 years after impoundment $\left(681.7 \pm 357 \mu \mathrm{mol} \mathrm{L}{ }^{-1}\right)$, followed by a gradual decrease since then

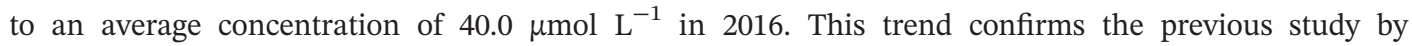

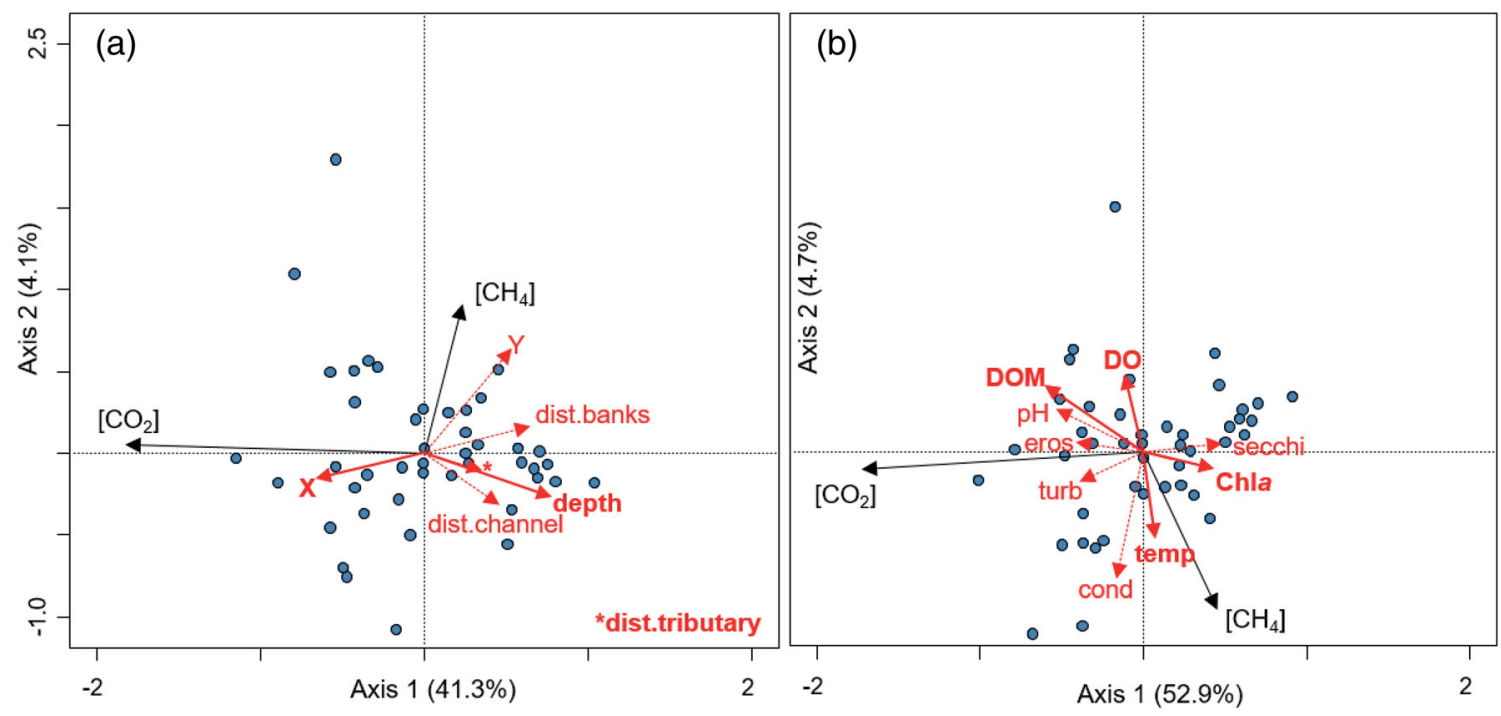

Figure 4. Redundancy analysis (RDA) triplot summarizing variation in the $\mathrm{CO}_{2}$ and $\mathrm{CH}_{4}$ concentrations across spatial (a) and environmental (b) explanatory variables. Red arrow represents explanatory variables. Arrows and variables in bold are significant according the stepwise selection. 


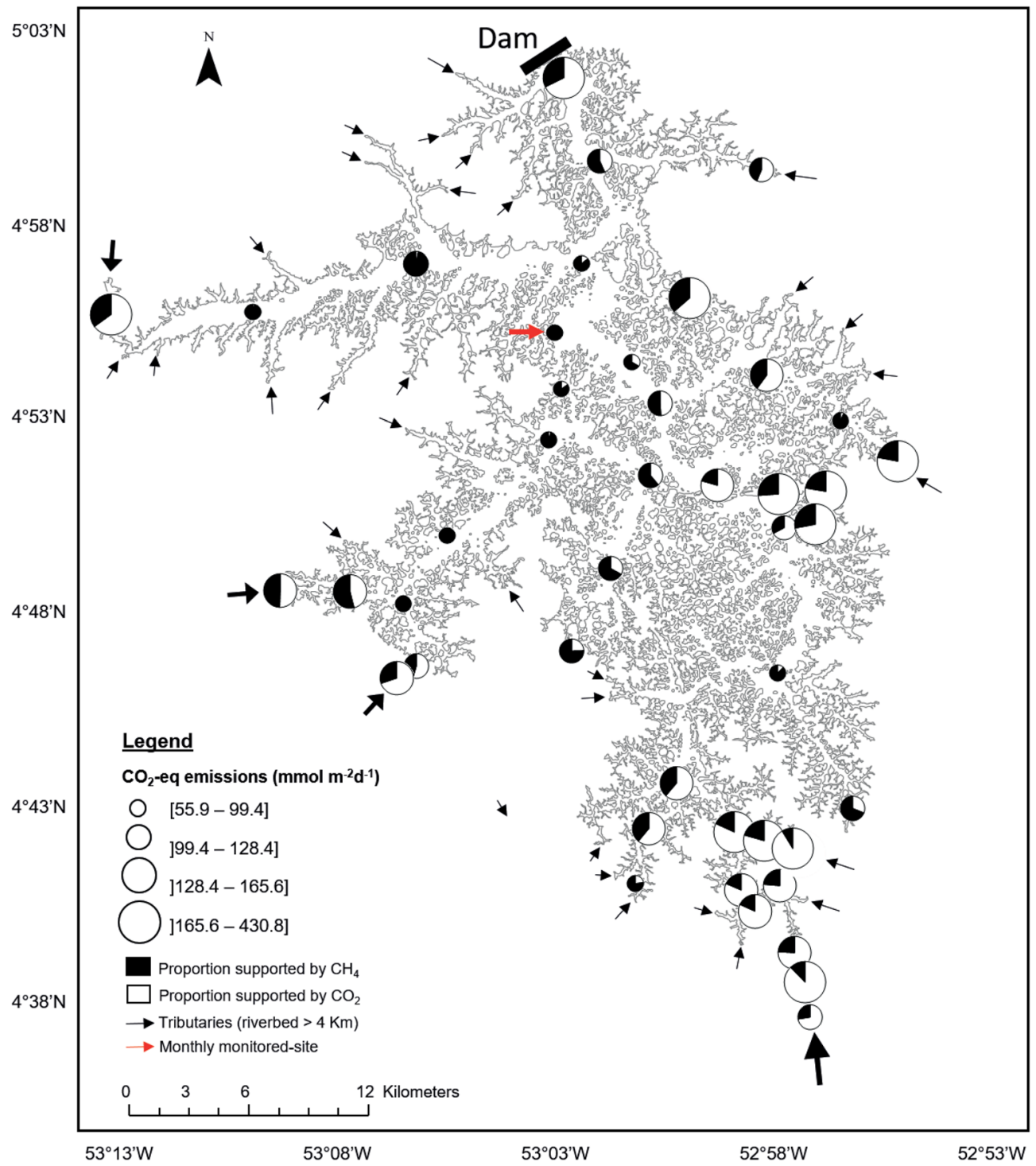

Figure 5. $\mathrm{CO}_{2}$-eq emissions $\left(\mathrm{mmol} \mathrm{m}^{-2}\right.$ day $^{-1}$ ) from direct measurements (black dots) at Petit-Saut reservoir. The size of dots has been created using bubble function in $\mathrm{R}$. The black fill indicates the proportion of $\mathrm{CO}_{2}$-eq emission supported by $\mathrm{CH}_{4}$; the white fill indicates the proportion supported by $\mathrm{CO}_{2}$. The black arrows indicate the main river entrances. The red arrow indicates the monthly monitored site (named "Roche Genipa").

Abril et al. (2005) that reported the decrease in depth-integrated $\mathrm{CH}_{4}$ concentrations at station Roche Genipa 10 years after impoundment. Since the initial soil flooded is probably the main C source in this central part of the reservoir (De Junet et al., 2005, 2009), this decreased $\mathrm{CH}_{4}$ concentration in the hypolimnion over time is likely due to its progressive decrease in quantity and bioavailability. $\mathrm{CH}_{4}$ surface water concentrations exhibited high temporal fluctuations with higher concentrations overall the 15 first years after impoundment $\left(1.19 \pm 1.0 \mu \mathrm{mol} \mathrm{L}^{-1}\right)$ and a strong decrease since 2009 to stabilize around $0.48 \pm 0.16 \mu \mathrm{mol} \mathrm{L}{ }^{-1}$ since then. This trend mirrors the decrease in $\mathrm{CH}_{4}$ concentrations in hypolimnion and, hence, the decrease in bioavailability of initial soil flooded C. Using temporal data and a "double-G" modeling approach, Abril et al. (2005) estimated that on the $10 \mathrm{Mt} \mathrm{C}$ initially flooded that only $42 \%$ would be biodegradable (including tree trunks and branches) and about $22 \%$ would have been lost to the atmosphere the first 10 years after impoundment. Considering this and the low hypolimnetic concentrations in $\mathrm{CH}_{4}$ reported here since 2010, it is likely that the major part of biodegradable $\mathrm{C}$ of the flooded soil has been already emitted to the atmosphere 24 years after impoundment and therefore that the $\mathrm{CH}_{4}$ concentrations in this monthly monitored site located in 
the central opened area would continue to decrease over time. In addition to the reduced stock in the initial flooded C, the decrease in the oxicline depth since 1996 at Roche Genipa favored methane oxidation by methanotrophic bacteria participating also in the significant decrease in methane concentrations at the water surface (Dumestre et al., 1999; Guérin \& Abril, 2007). The extreme events in surface $\mathrm{CH}_{4}$ concentrations are likely linked to interannual variation in hydrology, residence time (Abril et al., 2005; Striegl \& Michmerhuizen, 1998), or lateral inputs. For instance, high $\mathrm{CH}_{4}$ surface water concentrations that we measured in littoral areas may constitutes lateral inputs of $\mathrm{CH}_{4}$ for station Roche Genipa. The $\mathrm{CO}_{2}$ concentrations in surface and in depth exhibited quite similar temporal patterns. The $\mathrm{CO}_{2}$ surface water concentrations gradually decreased from 1997 until 2011 but increased since 2012. Yet the $\mathrm{CO}_{2}$ concentrations measured in 2016 were three times lower compared to concentrations measured the first years after impoundment. This recent trend may be related to the decrease in the oxicline depth over time, promoting methane oxidation that results in high surface $\mathrm{CO}_{2}$ concentrations or to highly seasonally dependent processes (e.g., phytoplankton growth dynamics and inputs of $\mathrm{CO}_{2}$ from the watershed or from the littoral areas). Indeed, both $\mathrm{CH}_{4}$ and $\mathrm{CO}_{2}$ concentrations exhibited high within-year variability. For instance, during the rainy season, oxicline depth increases and plunge inflow of tributaries in the reservoir allocate well-oxygenated water at the hypolimnion level, favoring methane oxidation. Consequently, $\mathrm{CO}_{2}$ concentrations tend to be highest during the wet season due to the inflow of main tributaries and methane oxidation. In contrast, epilimnetic $\mathrm{CH}_{4}$ concentrations tend to be lowest during the wet season due to the decreased residence time of water, the oxidation processes, and the increased gas transfer velocity (Guérin et al., 2007). This seasonal effect on gaseous concentrations is particularly strong in tropical reservoirs as exemplified here and stresses the importance of a monthly monitoring. In particular, one yearly sampling during low or high events may result in signifcant underestimates (in average $-69 \%$ for $\mathrm{CH}_{4}$ and $-75 \%$ for $\mathrm{CO}_{2}$ ) or overestimates (in average $+261 \%$ for $\mathrm{CH}_{4}$ and $+157 \%$ for $\mathrm{CO}_{2}$ ), respectively, of annual concentrations compared to an averaging of concentrations based on 12-month monitoring. Similarly, the strong interannual variations of $\mathrm{CH}_{4}$ and $\mathrm{CO}_{2}$ concentrations in surface and in depth stresses the importance of a temporally well-resolved monitoring of gas concentrations to accurately predict the long-term changes in GHGs emissions from one reservoir.

\subsection{Spatial Variability of $\mathrm{CH}_{4}$ and $\mathrm{CO}_{2}$ Concentrations 24 Years After Impounding}

Nonetheless, one sampling site at the central part of the reservoir may not be adequately representative of the total reservoir diffusive flux 24 years after impounding, while it might be well representative of the flux at the first years after impounding (Abril et al., 2005). Indeed, the time series analyses of gas concentrations at Roche Genipa suggest a decrease in the contribution of the initial flooded terrestrial OM to gaseous emissions over time. Assuming rather constant allochthonous inputs over time (no changes in riparian and watershed vegetation since impoundment), this could indicate that the relative contribution of allochthonous OM to GHG production in the reservoir increases in time in parallel with the decrease in the contribution of flooded terrestrial C. As a result, estimates of total diffusive emissions from the reservoir 24 years after impounding based on gas monitoring at Roche Genipa only underestimates the total gross emissions by $50.7 \%$ when expressed in $\mathrm{CO}_{2}$ equivalents compared to estimates based on the 44 sites due to a strong underestimation of diffusive $\mathrm{CO}_{2}$ emissions (-99.1\%). In contrast, Abril et al. (2005) reported that estimates of diffusive $\mathrm{CO}_{2}$ flux based on gas monitoring at Roche Genipa 10 years after impounding were adequately representative of the reservoir average ( $n=9$ sites). The high spatial variability in gas emissions highlights the need for high spatial resolution monitoring of gas concentrations to represent estimates of gas emissions from one reservoir. In particular, this could be worthwhile when reservoirs are aging due to changes in the relative contribution of the initial flooded biomass and other $\mathrm{C}$ sources including allochthonous OM to GHG production in the reservoir.

In particular, during our field campaign, 24 years after impounding, diffusive $\mathrm{CO}_{2}$ emissions close to tributaries were higher by 3 orders of magnitude compared to open areas sites. As suggested by the analysis of the environmental factors explaining the spatial variation in gas concentrations, high $\mathrm{CO}_{2}$ surface water concentrations in transitional areas are probably related to the riverine input of terrestrially respired $\mathrm{CO}_{2}$ and the mineralization of high deposition of OM coming from the tributaries (Bai et al., 2012; Cardoso et al., 2013). $\mathrm{CH}_{4}$ concentrations and emissions moderately varied within the reservoir compared to $\mathrm{CO}_{2}$ concentrations and emissions (CV: $92 \%$ for $\mathrm{CO}_{2}$ diffusive fluxes and $34 \%$ for diffusive $\mathrm{CH}_{4}$ fluxes). Yet, overall, littoral sites 
exhibited higher $\mathrm{CH}_{4}$ surface water concentrations and emissions than open and transition sites due to warm water and low oxygen concentrations at shallow littoral sites. Additionally, elevated deposition of $\mathrm{OM}$ in the littoral zones of reservoirs, combined with the mineralization of periodically inundated plant biomass, may favor high emission rates of $\mathrm{CH}_{4}$ (e.g., Fearnside \& Pueyo, 2012; Venkiteswaran et al., 2013; Yang et al., 2013; Zheng et al., 2011). We did not estimate the lateral and longitudinal inputs in allochthonous $\mathrm{C}$ in the reservoir, but they likely explain the high gas concentrations recorded in transitional and littoral areas. With 255 tributaries and a shoreline of about 3,800 km, both surrounded by a dense tropical forest combined with $105 \mathrm{~km}^{2}$ of forested islands, elevated input of allochthonous $\mathrm{C}$ is expected in transitional and littoral areas of PSR. In particular, we observed high leaf accumulation in sediments sampled in littoral and some transitional areas during the field campaign (Figure S3). We have a limited knowledge of the inputs, transport, and fate of airborn litterfall into reservoirs. Yet, considering that the litterfall of tropical rainforests in South America averages $4.0 \mathrm{t} \mathrm{C} \mathrm{ha}^{-1}$ year $^{-1}$ (Chave et al., 2010), it could be a significant source of $\mathrm{C}$ for the PSR surrounded by a dense tropical rainforest. Once in the reservoir, a portion of this OM is likely mineralized to $\mathrm{CO}_{2}$ or $\mathrm{CH}_{4}$ contributing to gas emissions (e.g., Bastviken et al., 2004; Furlanetto et al., 2012). For instance, De Faria et al. (2015) estimated that compared to the emissions from initial flooded soils, flooded foliage contributes to an average increase in $\mathrm{CH}_{4}$ and $\mathrm{CO}_{2}$ emissions of $33 \%$ and $28 \%$, respectively. It is likely that leaves process at very slow rates in the reservoir notably in the deepest areas, due to their refractory nature combined with low concentrations in DO (e.g., Ardón \& Pringle, 2008; Sobek et al., 2009; Wantzen et al., 2002). In laboratory incubations, Grasset et al. (2018) reported that fresh allochthonous materials (leaves) processed at very slow rates in anoxic sediments compared to autochthonous organic $\mathrm{C}$ (macrophytes and phytoplankton) and greatly increased $\mathrm{CH}_{4}$ production. For instance, we measured very slow decomposition rates (i.e., 562 days to yield 50\% of leaf mass loss) of Vismia Latifolia (Aubl., Choisy, 1821) leaves on four sites located in the littoral-flooded forest of PSR (unpublished data) confirming that a substantial part of leaf inputs to littoral zones accumulates in sediments and potentially fuels methanogenesis (Conrad, 2007).

Additionally, we cannot exclude that C-derived from submerged trunks may also contribute to $\mathrm{CH}_{4}$ and $\mathrm{CO}_{2}$ emissions while we have a limited knowledge of their fate since the impounding. Indeed, as for most of tropical reservoirs (Gilani \& Innes, 2017), trees were not removed prior to flooding at PSR (except locally upstream the dam), and 24 years after, most submerged trunks remain upright and seem relatively well preserved, probably thanks to anoxic conditions. Some studies reported the decrease in surface wood density with time using qualitative approaches and suggested that $\mathrm{C}$ derived from trunks may contribute to long-term gaseous emissions (Abril et al., 2013; Campo \& Sancholuz, 1998). However, to date, no quantitative data are available on the fate of both surface and submerged trunks and their contribution to GHG emissions. It is unlikely that submerged trunks directly and significantly participate in $\mathrm{CH}_{4}$ an $\mathrm{CO}_{2}$ emissions, but some studies reported gas fluxes from trunks of living trees by molecular diffusion of sediment-derived gas (see review of Covey \& Megonigal, 2019). This emission pathway remains unexplored in reservoirs. On the contrary, trunks may reduce $\mathrm{CO}_{2}$ evasion to the atmosphere when colonized by autotrophic biofilms (Huguet et al., 2010), while primary production is globally low in pelagic and open areas. Considering that trees are mostly not cut down before impoundment, there is an urgent need to elucidate their potential contribution to GHG emissions.

\subsection{Perspectives}

This study did not aim to estimate the net $\mathrm{C}$ budget of the reservoir. Yet the high spatial variability in $\mathrm{CH}_{4}$ and $\mathrm{CO}_{2}$ surface water concentrations and diffusive emissions reported here highlight the heterogeneity of $\mathrm{C}$ sources that may be involved in long-term gas emissions from the reservoir. Further studies are needed to disentangle the origin of these $\mathrm{C}$ sources and, notably, the respective contribution of the initial $\mathrm{C}$ flooded (soil, trunks) and the allochthonous OC. Such knowledge is crucial to accurately allocate emissions attributable to the reservoir itself (net emissions) and predict long-term emissions. For instance, the high $\mathrm{CH}_{4}$ and $\mathrm{CO}_{2}$ concentrations and emissions in both transitional and littoral areas compared to the open area of the reservoir, albeit measured during only one campaign, suggest that the mineralization of allochthonous $\mathrm{C}$ coming from tributaries and surrounding rainforest is a major process responsible for a significant part of the current gross emissions from the reservoir. This is confirmed by the decreased gas concentrations over time at the monthly monitored site located in the open central area where the $\mathrm{C}$ source is primarily initial 
flooded C. If we consider what the atmosphere sees (net emissions; Prairie et al., 2018) a part of the GHG related to the mineralization of allochthonous $\mathrm{C}$ coming from tributaries or surrounded rainforest would have been converted into GHG, mostly $\mathrm{CO}_{2}$, and returned to the atmosphere over short timescales even without the reservoir. This fraction must be removed to the net GHG footprint of the reservoir. Consequently, the increased relative contribution of allochthonous OM to GHG from the reservoir over time would lead to a decrease in net emission. However, the estimation of the fraction of gross emissions to include in the reservoir GHG net budget is a complex task. In particular, this is complicated by a limited knowledge of the lateral and longitudinal transports of $\mathrm{C}$ from terrestrial ecosystems into reservoirs and the way it is processed (i.e., stored or mineralized in $\mathrm{CO}_{2}$ or $\mathrm{CH}_{4}$ ). This stresses the importance of taking into account the $\mathrm{C}$ sources (initial stock or allochthonous), and its evolution with time, when assessing the spatial variability in $\mathrm{CH}_{4}$ and $\mathrm{CO}_{2}$ emissions to apportion correctly the part of GHG emissions that can be legitimately attributed to the creation of the reservoir itself. This field remains however largely unexplored to date.

This study examined gas diffusive fluxes without regard to ebullition since a previous study reported it is the main emission pathway within the reservoir for $\mathrm{CO}_{2}(89 \%)$ and for $\mathrm{CH}_{4}(76 \%)$ (Abril et al., 2005). Yet the spatiotemporal variability of the ebullitive $\mathrm{CH}_{4}$ flux has not been accurately addressed at Petit-Saut while the contribution of such a pathway to the total gas emissions by the reservoir likely exhibits high spatial and temporal variability (e.g., DelSontro et al., 2011; Linkhorst et al., 2020). In particular, ebullition may be an important emissions pathway notably in littoral and transition areas and therefore may exhibit a similar spatial variation to the diffusive flux that we reported here. For instance, $\mathrm{CH}_{4}$ ebullition fluxes may be substantially high in transition areas due to river supply allochthonous organic material, relatively low depth and shear stress in sediments caused by bottom currents (DelSontro et al., 2011; Joyce \& Jewell, 2003). Further studies are needed to examine how the ebullition pathway varies in time and space within the reservoir and the consequences for estimates in total gas emissions from the reservoir.

\section{Conclusion}

In this study, long-term (22 years) monitoring data at a single point associated with a punctual measurement campaign (44 stations) give valuable and complementary information on GHG emissions from the PSR. Long-term monitoring data are rare, and most studies used comparisons of reservoirs with different ages of impoundment to predict long-term emissions. Nevertheless, such an approach requires caution as tropical reservoirs belong to different biomes and finally studies on Amazonian reservoirs are rare (Table S2). The long-term monitoring at one site in the central open-water part of PSR shows a substantial continuous decrease of $\mathrm{CO}_{2}$ and $\mathrm{CH}_{4}$ concentration in the water since the impoundment, with high seasonal variations. However, gross diffusive $\mathrm{CH}_{4}$ fluxes remain high 23 years after the impoundment: $\sim 2.2$-fold $\left(n=15 ; 2.01 \pm 1.6 \mathrm{mmol} \mathrm{m}^{-2}\right.$ day $\left.^{-1}\right)$ and $\sim 1.2$-fold $\left(n=6 ; 3.92 \pm 4.12 \mathrm{mmol} \mathrm{m}^{-2}\right.$ day $\left.^{-1}\right)$ higher than emissions from others tropical and Amazonian reservoirs, respectively, independently of reservoir age (Table S2). Such a difference may be related to heterogeneity of methodologies used for measuring fluxes (e.g., floating chambers or fluxes derived from concentrations) or dependent on climatic or hydrologic confounding factors causing such comparisons merit caution. Yet higher diffusive fluxes at PSR compared to non-Amazonian reservoirs may be merely related to the contribution of allochthonous OM from the surrounding dense rainforest, missing for non-Amazonian reservoirs. Indeed, in our study, the high-spatial resolution campaign in 2018 revealed a high variability in GHG concentration/diffusion fluxes between open, littoral, and river-reservoir transition areas. This variability was evidenced only during one campaign at the dry season, and results must be considered with care. Indeed, the time series analyses showed the high seasonal effect on gas concentration at a central site of the reservoir in particular, with highest $\mathrm{CH}_{4}$ concentrations and lowest $\mathrm{CO}_{2}$ concentrations during the dry season. Nevertheless, it appears clearly that higher concentrations in the littoral and transitional zones are due to the preferential input of allochthonous $\mathrm{C}$ in these areas. Not considering the contribution of the allochthonous $\mathrm{C}$ source could lead to a severe underestimation of the gross diffusive GHG fluxes at the whole reservoir scale. However, the question remains open as regard the contribution of these allochthonous $\mathrm{C}$ sources on the net GHG footprint of the reservoir (e.g., part of $\mathrm{CO}_{2}$ emissions due to this $\mathrm{C}$ source would have 
occurred even without a reservoir). In summary, our results confirm the significance of GHG emissions from this tropical reservoir and stress the importance of the following:

1. well-resolved temporally and spatially monitoring of surface water $\mathrm{CO}_{2}$ and $\mathrm{CH}_{4}$ concentrations to achieve a representative estimate of diffusive $\mathrm{CO}_{2}$ and $\mathrm{CH}_{4}$ emissions;

2. considering the contribution of littoral and transition zones in $\mathrm{C}$ concentration/diffusion fluxes when upscaling emissions rates at the global scale;

3. taking into account the importance of input and degradation of allochthonous $\mathrm{C}$ as a major process contributing to long-term diffusive gaseous emissions.

\section{Data Availability Statement}

The data on spatial variability of gas concentrations and environmental drivers are available in Mendeley repository (https://doi.org/10.17632/h7t78kxjjw.1). The data on time series are restricted, but researchers can gain access by contacting the reservoir owner (EDF, France).

\section{Acknowledgments}

We would like to thank the staff at Hydreco laboratory for field assistance. We also thank Yves Prairie for his advises in the collection of data and calculations. This study was supported by the French Agency for Biodiversity. The authors are grateful to the anonymous reviewers for their suggestions that have significantly improved the quality of the manuscript.

\section{References}

Abril, G., Guérin, F., Richard, S., Delmas, R., Galy-Lacaux, C., Gosse, P., et al. (2005). Carbon dioxide and methane emissions and the carbon budget of a 10-year old tropical reservoir (Petit Saut, French Guiana). Global Biogeochemical Cycles, 19, GB4007. https://doi.org/ $10.1029 / 2005$ GB002457

Abril, G., Parize, M., Pérez, M. A., \& Filizola, N. (2013). Wood decomposition in Amazonian hydropower reservoirs: An additional source of greenhouse gases. Journal of South American Earth Sciences, 44, 104-107. https://doi.org/10.1016/j.jsames.2012.11.007

Almeida, R. M., Nóbrega, G. N., Junger, P. C., Figueiredo, A. V., Andrade, A. S., de Moura, C. G. B., et al. (2016). High primary production contrasts with intense carbon emission in a eutrophic tropical reservoir. Frontiers in Microbiology, 7. https://doi.org/10.3389/ fmicb.2016.00717

Almeida, R. M., Shi, Q., Gomes-Selman, J. M., Wu, X., Xue, Y., Angarita, H., et al. (2019). Reducing greenhouse gas emissions of Amazon hydropower with strategic dam planning. Nature Communications, 10(1). https://doi.org/10.1038/s41467-019-12179-5

Amorocho, J., \& DeVries, J. J. (1980). A new evaluation of the wind stress coefficient over water surfaces. Journal of Geophysical Research, 85(C1), 433. https://doi.org/10.1029/JC085iC01p00433

Ardón, M., \& Pringle, C. M. (2008). Do secondary compounds inhibit microbial- and insect-mediated leaf breakdown in a tropical rainforest stream, Costa Rica? Oecologia, 155(2), 311-323. https://doi.org/10.1007/s00442-007-0913-X

Bai, Y., Shi, Q., Wen, D., Li, Z., Jefferson, W. A., Feng, C., \& Tang, X. (2012). Bacterial communities in the sediments of Dianchi Lake, a partitioned eutrophic waterbody in China. PLoS ONE, 7(5), e37796. https://doi.org/10.1371/journal.pone.0037796

Barros, N., Cole, J. J., Tranvik, L. J., Prairie, Y. T., Bastviken, D., Huszar, V. L., et al. (2011). Carbon emission from hydroelectric reservoirs linked to reservoir age and latitude. Nature Geoscience, 4(9), 593-596. https://doi.org/10.1038/ngeo1211

Bastviken, D., Cole, J., Pace, M., \& Tranvik, L. (2004). Methane emissions from lakes: Dependence of lake characteristics, two regional assessments, and a global estimate. Global Biogeochemical Cycles, 18, GB4009. https://doi.org/10.1029/2004GB002238

Blanchet, F. G., Legendre, P., \& Borcard, D. (2008). Forward selection of explanatory variables. Ecology, 89(9), 2623-2632. https://doi.org/ 10.1890/07-0986.1

Blasing, T. J. (2009). Recent greenhouse gas concentrations [data set]. Oak Ridge National Laboratory. https://doi.org/10.3334/CDIAC/ atg.032

Campo, J., \& Sancholuz, L. (1998). Biogeochemical impacts of submerging forests through large dams in the Río Negro, Uruguay. Journal of Environmental Management, 54(1), 59-66. https://doi.org/10.1006/jema.1998.0222

Cardoso, S. J., Vidal, L. O. V., Mendonça, R. F., Tranvik, L. J., Sobek, S., \& Roland, F. (2013). Spatial variation of sediment mineralization supports differential $\mathrm{CO}_{2}$ emissions from a tropical hydroelectric reservoir. Frontiers in Microbiology, 4, 101. https://doi.org/10.3389/ fmicb.2013.00101

Chanudet, V., Gaillard, J., Lambelain, J., Demarty, M., Descloux, S., Félix-Faure, J., et al. (2020). Emission of greenhouse gases from French temperate hydropower reservoirs. Aquatic Sciences, 82(3), 51. https://doi.org/10.1007/s00027-020-00721-3

Chave, J., Navarrete, D., Almeida, S., Álvarez, E., Aragão, L. E. O. C., Bonal, D., et al. (2010). Regional and seasonal patterns of litterfall in tropical South America. Biogeosciences, 7(1), 43-55. https://doi.org/10.5194/bg-7-43-2010

Chen, H., Wu, Y., Yuan, X., Gao, Y., Wu, N., \& Zhu, D. (2009). Methane emissions from newly created marshes in the drawdown area of the Three Gorges Reservoir. Journal of Geophysical Research, 114, D18301. https://doi.org/10.1029/2009JD012410

Chessel, D., Dufour, A. B., \& Thioulouse, J. (2004). The ade4 package-I—One-table methods. $R$ News, 4, 5-10.

Cleveland, R. B., Cleveland, W. S., McRae, J. E., \& Terpenning, I. (1990). STL: A seasonal-trend decomposition. Journal of Official Statistics, $6(1), 3-73$.

Cole, J. J., \& Caraco, N. F. (1998). Atmospheric exchange of carbon dioxide in a low-wind oligotrophic lake measured by the addition of SF6. Limnology and Oceanography, 43(4), 647-656. https://doi.org/10.4319/lo.1998.43.4.0647

Conrad, R. (2007). Microbial ecology of methanogens and methanotrophs. Advances in Agronomy, 96, 1-63. https://doi.org/10.1016/S00652113(07)96005-8

Covey, K. R., \& Megonigal, J. P. (2019). Methane production and emissions in trees and forests. New Phytologist, 222(1), 35-51. https://doi. org/10.1111/nph.15624

De Faria, F. A., Jaramillo, P., Sawakuchi, H. O., Richey, J. E., \& Barros, N. (2015). Estimating greenhouse gas emissions from future Amazonian hydroelectric reservoirs. Environmental Research Letters, 10, 124019. https://doi.org/10.1088/1748-9326/10/12/ 124019

De Junet, A., Abril, G., Guérin, F., Billy, I., \& De Wit, R. (2005). Sources and transfers of particulate organic matter in a tropical reservoir (Petit Saut, French Guiana): A multi-tracers analysis using d ${ }^{13} \mathrm{C}, \mathrm{C} / \mathrm{N}$ ratio and pigments. Biogeosciences Discussions, 2(4), $1159-1196$. https://doi.org/10.5194/bgd-2-1159-2005 
De Junet, A., Abril, G., Guérin, F., Billy, I., \& De Wit, R. (2009). A multi-tracers analysis of sources and transfers of particulate organic matter in a tropical reservoir (Petit Saut, French Guiana). River Research and Applications, 25(3), 253-271. https://doi.org/10.1002/ rra.1152

Deemer, B. R., Harrison, J. A., Li, S., Beaulieu, J. J., DelSontro, T., Barros, N., et al. (2016). Greenhouse gas emissions from reservoir water surfaces: A new global synthesis. Bioscience, 66(11), 949-964. https://doi.org/10.1093/biosci/biw117

Delmas, R., Richard, S., Guérin, F., Abril, G., Galy-Lacaux, C., Delon, C., \& Grégoire, A. (2005). Long term greenhouse gas emissions from the hydroelectric reservoir of Petit Saut (French Guiana) and potential impacts. In Greenhouse gas emissions-Fluxes and processes (pp. 293-312). Berlin: Springer.

DelSontro, T., Beaulieu, J. J., \& Downing, J. A. (2018). Greenhouse gas emissions from lakes and impoundments: Upscaling in the face of global change: GHG emissions from lakes and impoundments. Limnology and Oceanography Letters, 3, 64-75. https://doi.org/10.1002/ lol2.10073

DelSontro, T., Kunz, M. J., Kempter, T., Wüest, A., Wehrli, B., \& Senn, D. B. (2011). Spatial heterogeneity of methane ebullition in a large tropical reservoir. Environmental Science \& Technology, 45(23), 9866-9873. https://doi.org/10.1021/es2005545

Deshmukh, C., Serça, D., Delon, C., Tardif, R., Demarty, M., Jarnot, C., et al. (2014). Physical controls on $\mathrm{CH}_{4}$ emissions from a newly flooded subtropical freshwater hydroelectric reservoir: Nam Theun 2. Biogeosciences, 11, 4251-4269. https://doi.org/10.5194/ bg-11-4251-2014

Dumestre, J.-F., Vaquer, A., Gosse, P., Richard, S., \& Labroue, L. (1999). Bacterial ecology of a young equatorial hydroelectric reservoir (Petit Saut, French Guiana). Hydrobiologia, 400, 75-83. https://doi.org/10.1023/A:1003707129170

Fearnside, P. M. (1995). Hydroelectric dams in the Brazilian Amazon as sources of "greenhouse" gases. Environmental Conservation, 22(1), 7-19. https://doi.org/10.1017/S0376892900034020

Fearnside, P. M., \& Pueyo, S. (2012). Greenhouse-gas emissions from tropical dams. Nature Climate Change, 2(6), 382-384. https://doi.org/ $10.1038 /$ nclimate 1540

Furlanetto, L. M., Marinho, C. C., Palma-Silva, C., Albertoni, E. F., Figueiredo-Barros, M. P., \& de Assis Esteves, F. (2012). Methane levels in shallow subtropical lake sediments: Dependence on the trophic status of the lake and allochthonous input. Limnologica, 42(2), 151-155. https://doi.org/10.1016/j.limno.2011.09.009

Galy-Lacaux, C., Delmas, R., Kouadio, G., Richard, S., \& Gosse, P. (1999). Long-term greenhouse gas emissions from hydroelectric reservoirs in tropical forest regions. Global Biogeochemical Cycles, 13(2), 503-517. https://doi.org/10.1029/1998GB900015

Gilani, H. R., \& Innes, J. L. (2017). Environmental and social aspects of underwater logging. Geoforum, 86, 188-191. https://doi.org/ 10.1016/j.geoforum.2017.09.018

Grasset, C., Mendonça, R., Villamor Saucedo, G., Bastviken, D., Roland, F., \& Sobek, S. (2018). Large but variable methane production in anoxic freshwater sediment upon addition of allochthonous and autochthonous organic matter: Methanogenic potential of different OC types. Limnology and Oceanography, 63, 1488-1501. https://doi.org/10.1002/lno.10786

Guérin, F., \& Abril, G. (2007). Significance of pelagic aerobic methane oxidation in the methane and carbon budget of a tropical reservoir: $\mathrm{CH}_{4}$ oxidation in a tropical reservoir. Journal of Geophysical Research, 112, G03006. https://doi.org/10.1029/2006JG000393

Guérin, F., Abril, G., de Junet, A., \& Bonnet, M.-P. (2008). Anaerobic decomposition of tropical soils and plant material: Implication for the $\mathrm{CO}_{2}$ and $\mathrm{CH}_{4}$ budget of the Petit Saut Reservoir. Applied Geochemistry, 23(8), 2272-2283. https://doi.org/10.1016/j. apgeochem.2008.04.001

Guérin, F., Abril, G., Serça, D., Delon, C., Richard, S., Delmas, R., et al. (2007). Gas transfer velocities of $\mathrm{CO}_{2}$ and $\mathrm{CH}_{4}$ in a tropical reservoir and its river downstream. Journal of Marine Systems, 66(1-4), 161-172. https://doi.org/10.1016/j.jmarsys.2006.03.019

Hiemstra, P., \& Hiemstra, M. P. (2013). Package "automap". Compare, 105, 10.

Huguet, L., Castelle, S., Schäfer, J., Blanc, G., Maury-Brachet, R., Reynouard, C., \& Jorand, F. (2010). Mercury methylation rates of biofilm and plankton microorganisms from a hydroelectric reservoir in French Guiana. Science of the Total Environment, 408(6), 1338-1348. https://doi.org/10.1016/j.scitotenv.2009.10.058

Huynh, F., Demagistri, L., Garrouste, V., Charron, C., Panechou, K., Gardel, A., et al. (1996). Cartographie de la retenue du barrage de Petit-Saut aux cotes 31 et 35 metres. In Convention ORSTOM/EDF, Paris.

Hyndman, R. J., Athanasopoulos, G., Bergmeir, C., Caceres, G., Chhay, L., O'Hara-Wild, M., et al. (2019). Package “forecast”. (Online) https://cran.r-project.org/web/packages/forecast/forecast.pdf

IPCC (2014). Fifth Assessment Report (AR5). Press: Cambridge Univ.

Jähne, B., Münnich, K. O., Bösinger, R., Dutzi, A., Huber, W., \& Libner, P. (1987). On the parameters influencing air-water gas exchange. Journal of Geophysical Research, 92(C2), 1937-1949. https://doi.org/10.1029/JC092iC02p01937

Joyce, J., \& Jewell, P. W. (2003). Physical controls on methane ebullition from reservoirs and lakes. Environmental \& Engineering Geoscience, 9(2), 167-178. https://doi.org/10.2113/9.2.167

Kemenes, A., Forsberg, B. R., \& Melack, J. M. (2011). $\mathrm{CO}_{2}$ emissions from a tropical hydroelectric reservoir (Balbina, Brazil). Journal of Geophysical Research, 116, G03004. https://doi.org/10.1029/2010JG001465

Legendre, P., \& Legendre, L. F. (2012). Numerical ecology (Vol. 24). Oxford: Elsevier.

Linkhorst, A., Hiller, C., DelSontro, T., Azevedo, G. M., Barros, N., Mendonça, R., \& Sobek, S. (2020). Comparing methane ebullition variability across space and time in a Brazilian reservoir. Limnology and Oceanography, 65(7), 1623-1634. https://doi.org/10.1002/ lno. 11410

Liss, P. S., \& Merlivat, L. (1986). Air-sea gas exchange rates: Introduction and synthesis. In The role of air-sea exchange in geochemical cycling (pp. 113-127). Dordrecht: Springer.

Maeck, A., DelSontro, T., McGinnis, D. F., Fischer, H., Flury, S., Schmidt, M., et al. (2013). Sediment trapping by dams creates methane emission hot spots. Environmental Science \& Technology, 47(15), 8130-8137. https://doi.org/10.1021/es4003907

Nogueria, M. G., Perbiche-Neves, G., de Oliveira Naliato, C., \& Gokce, D. (2019). Limnological Patterns in a Large Subtropical Reservoir Cascade. In Limnology - Some New Aspects of Inland Water Ecology (pp. 3-37). London: IntechOpen. Retrieved from https://www. intechopen.com/books/limnology-some-new-aspects-of-inland-water-ecology/limnological-patterns-in-a-large-subtropical-reservoircascade

Oksanen, J., Blanchet, F. G., Kindt, R., Legendre, P., Minchin, P. R., O'hara, R. B., et al. (2013). Package "vegan”. Community Ecology Package, Version, 2, 1-295. Retrieved from. http://cran.ism.ac.jp/web/packages/vegan/vegan.pdf

Ometto, J. P., Cimbleris, A. C. P., dos Santos, M. A., Rosa, L. P., Abe, D., Tundisi, J. G., et al. (2013). Carbon emission as a function of energy generation in hydroelectric reservoirs in Brazilian dry tropical biome. Energy Policy, 58, 109-116. https://doi.org/10.1016/j. enpol.2013.02.041 
Pacheco, F. S., Soares, M. C. S., Assireu, A. T., Curtarelli, M. P., Roland, F., Abril, G., et al. (2015). The effects of river inflow and retention time on the spatial heterogeneity of chlorophyll and water-air $\mathrm{CO}_{2}$ fluxes in a tropical hydropower reservoir. Biogeosciences, 12, 147-162. https://doi.org/10.5194/bg-12-147-2015

Paranaíba, J. R., Barros, N., Mendonça, R., Linkhorst, A., Isidorova, A., Roland, F., et al. (2018). Spatially resolved measurements of CO and $\mathrm{CH}_{4}$ concentration and gas-exchange velocity highly influence carbon-emission estimates of reservoirs. Environmental Science \& Technology, 52, 607-615. https://doi.org/10.1021/acs.est.7b05138

Pebesma, E., Graeler, B., \& Pebesma, M. E. (2018). Package "gstat".

Prairie, Y. T., Alm, J., Beaulieu, J., Barros, N., Battin, T., Cole, J., et al. (2018). Greenhouse gas emissions from freshwater reservoirs: What does the atmosphere see? Ecosystems, 21(5), 1058-1071. https://doi.org/10.1007/s10021-017-0198-9

R Development Core Team (2008). R: A language and environment for statistical computing. Vienna, Austria: R Foundation for Statistical Computing. Retrieved from http://www.R-project.org

Raymond, P. A., Hartmann, J., Lauerwald, R., Sobek, S., McDonald, C., Hoover, M., et al. (2013). Global carbon dioxide emissions from inland waters. Nature, 503, 355-359. https://doi.org/10.1038/nature12760

Roland, F., Vidal, L. O., Pacheco, F. S., Barros, N. O., Assireu, A., Ometto, J. P., et al. (2010). Variability of carbon dioxide flux from tropical (Cerrado) hydroelectric reservoirs. Aquatic Sciences, 72(3), 283-293. https://doi.org/10.1007/s00027-010-0140-0

Rosa, L. P., Dos Santos, M. A., Matvienko, B., Sikar, E., Lourenço, R. S. M., \& Menezes, C. F. (2003). Biogenic gas production from major Amazon reservoirs, Brazil. Hydrological Processes, 17(7), 1443-1450. https://doi.org/10.1002/hyp.1295

Sobek, S., DelSontro, T., Wongfun, N., \& Wehrli, B. (2012). Extreme organic carbon burial fuels intense methane bubbling in a temperate reservoir. Geophysical Research Letters, 39, L01401. https://doi.org/10.1029/2011GL050144

Sobek, S., Durisch-Kaiser, E., Zurbrügg, R., Wongfun, N., Wessels, M., Pasche, N., \& Wehrli, B. (2009). Organic carbon burial efficiency in lake sediments controlled by oxygen exposure time and sediment source. Limnology and Oceanography, 54(6), 2243-2254. https://doi. org/10.4319/lo.2009.54.6.2243

St. Louis, V. L., Kelly, C. A., Duchemin, É., Rudd, J. W., \& Rosenberg, D. M. (2000). Reservoir surfaces as sources of greenhouse gases to the atmosphere: A global estimate: Reservoirs are sources of greenhouse gases to the atmosphere, and their surface areas have increased to the point where they should be included in global inventories of anthropogenic emissions of greenhouse gases. AIBS Bulletin, 50(9), 766-775. https://doi.org/10.1641/0006-3568(2000)050[0766:rsasog]2.0.co;2

Striegl, R. G., \& Michmerhuizen, C. M. (1998). Hydrologic influence on methane and carbon dioxide dynamics at two north-central Minnesota lakes. Limnology and Oceanography, 43(7), 1519-1529. https://doi.org/10.4319/lo.1998.43.7.1519

Thornton, K. W. (1990). In K. W. Thornton, B. L. Kimmel, F. E. Payne (Eds.), Perspectives on reservoir limnology, in Reservoir Limnology: Ecological Perspectives (pp. 1-13). New York: John Wiley.

Tremblay, A. (2005). Greenhouse gas emissions_Fluxes and processes: Hydroelectric reservoirs and natural environments. Berlin: Springer Science \& Business Media. https://doi.org/10.1007/b137840

Venkiteswaran, J. J., Schiff, S. L., Louis, V. L. S., Matthews, C. J., Boudreau, N. M., Joyce, E. M., et al. (2013). Processes affecting greenhouse gas production in experimental boreal reservoirs. Global Biogeochemical Cycles, 27, 567-577. https://doi.org/10.1002/gbc.20046

Wanninkhof, R. (1992). Relationship between wind speed and gas exchange over the ocean. Journal of Geophysical Research, 97(C5), 7373. https://doi.org/10.1029/92JC00188

Wantzen, K. M., Wagner, R., Suetfeld, R., \& Junk, W. J. (2002). How do plant-herbivore interactions of trees influence coarse detritus processing by shredders in aquatic ecosystems of different latitudes? Internationale Vereinigung Für Theoretische Und Angewandte Limnologie: Verhandlungen, 28(2), 815-821. https://doi.org/10.1080/03680770.2001.11901827

Wetzel, R. G. (2001). Limnology (3rd ed.). San Diego, CA: Academic Press.

Winslow, L. (2019). Package "rLakeAnalyzer" (Version 1.11.4.1) [R]. Retrieved from https://cran.r-project.org/web/packages/ rLakeAnalyzer

Yang, L., Lu, F., Wang, X., Duan, X., Song, W., Sun, B., et al. (2012). Surface methane emissions from different land use types during various water levels in three major drawdown areas of the Three Gorges Reservoir. Journal of Geophysical Research, 117, D10109. https://doi. org/10.1029/2011JD017362

Yang, L., Lu, F., Wang, X., Duan, X., Tong, L., Ouyang, Z., \& Li, H. (2013). Spatial and seasonal variability of $\mathrm{CO}_{2}$ flux at the air-water interface of the Three Gorges Reservoir. Journal of Environmental Sciences, 25, 2229-2238. https://doi.org/10.1016/S1001-0742(12) 60291-5

Zarfl, C., Lumsdon, A. E., Berlekamp, J., Tydecks, L., \& Tockner, K. (2015). A global boom in hydropower dam construction. Aquatic Sciences, 77, 161-170. https://doi.org/10.1007/s00027-014-0377-0

Zheng, H., Zhao, X., Zhao, T., Chen, F., Xu, W., Duan, X., et al. (2011). Spatial-temporal variations of methane emissions from the Ertan hydroelectric reservoir in southwest China. Hydrological Processes, 25(9), 1391-1396. https://doi.org/10.1002/hyp.7903 